\title{
Factor analysis techniques for assessing sufficient unidimensionality of cancer related fatigue
}

\author{
Jin-Shei Lai $\cdot$ Paul K. Crane $\cdot$ David Cella
}

Published online: 10 March 2007

(C) Springer Science+Business Media B.V. 2007

Erratum to: Qual Life Res (2006) 15: 1179-1190

DOI 10.1007/s11136-006-0060-6

The e-mail address on the first page of the original was incorrect. The corresponding author's correct e-mail address is shown below.

The online version of the original article can be found at http:// dx.doi.org/10.1007/s11136-006-0060-6

J.-S. Lai $(\bowtie) \cdot$ D. Cella

Center on Outcomes, Research and Education (CORE),

Evanston Northwestern Healthcare and Northwestern

University, Evanston, USA

e-mail: js-lai@northwestern.edu

\section{P. K. Crane}

Division of General Internal Medicine, University of

Washington, Seattle, Washington, USA 